\title{
An Examination of Thinness and Overweight in Children Using W.H.O. BMI Categories before and after Intestinal Parasite Intervention
}

\author{
Claris Smith $^{1, *}$, Renee Owusu-Ansah ${ }^{2}$, William Sorensen ${ }^{1}$ \\ ${ }^{1}$ University of Texas at Tyler, Department of Health and Kinesiology \\ ${ }^{2}$ Victoria, Texas Office of Emergency Management \\ *Corresponding author: claris.smith@gmail.com
}

Received March 25, 2015; Revised April 05, 2015; Accepted April 09, 2015

\begin{abstract}
This study is a secondary analysis to identify the effects of as oil transmitted helminth treatment campaign on growth in Guatemalan children, and to identify other factors associated with change in BMI. One thousand children were recruited through schools, pre and post BMI was calculated from height and weight measures with a helminth treatment campaign as the timeframe. BMI was categorized into WHO standard categories, and collapsed into binary risk variables (extreme thin vs. all others, and extreme overweight vs. all others). From this, predictors of BMI change were identified. Older age predicted thinness. Younger age and rural residence predicted overweight. Helminth treatment had no effect on BMI growth. East Guatemalan children progress toward thinness naturally. Caution is urged in using BMI as the sole tool for measuring growth in children.
\end{abstract}

\section{Keywords: BMI Standards, children, Guatemala, Helminth Intervention}

Cite This Article: Claris Smith, Renee Owusu-Ansah, and William Sorensen, "An Examination of Thinness and Overweight in Children Using W.H.O. BMI Categories before and after Intestinal Parasite Intervention." American Journal of Public Health Research, vol. 3, no. 3 (2015): 91-94. doi: 10.12691/ajphr-3-3-2.

\section{Introduction}

Between a third and half of all Guatemalan children are chronically malnourished, with a greater burden among indigenous families [1]. Sorensen and colleagues [2] observed stunting in $17 \%$ of east Guatemalan children, but acute malnutrition (wasting) was found among half. Guatemala has the highest rate of childhood malnutrition in Latin America despite being the world's fifth largest exporter of food commodities. In 2010, over two thousand Guatemalan children under the age of 5 died as a result of malnutrition [3], an alarming number in a nation with only 14 million inhabitants [4].

Malnutrition contributes to childhood mortality by exacerbating the effects of preventable and treatable diseases [5]. Research suggests that one third to one half of all child deaths globally are associated with malnutrition [6]. In addition to morbidity and mortalityrisk, malnutrition induces other deleterious effects, including mental and physical development delays $[1,7,8]$.

Malnutrition is traditionally a term associated with thinness, but overweight and obesity status can be malnutrition. Overweight/obesity was coined by the World Bank as the "double burden of malnutrition [9]", an emerging public health concern in children associated with an increased prevalence of chronic conditions including hypertension, hypercholesteremia, diabetes, cancer and cardiovascular disease $[9,10]$.
Malnutrition in children has been traditionally difficult to quantify. Traditional methods use weight for height and height for age, and were based on United States references [8]. In addition, neither is considered a stable measure for thinness [11,12]. Later research suggests that Body Mass Index (BMI) is a good indicator for thinness and overweight in developing children [11,13] which better adjusts for age. Since 2006, the World Health Organization (WHO) has created global standards for children's growth based on BMI measures. The standards can monitor growth of children regardless of ethnicity or socioeconomic status (SES) [8].

The purpose of this study was to 1 . Determine if soil transmitted helminth and/or helminth treatment impacts the BMI in Guatemalan children, and 2. Identify other factors which may associate with children's BMI.

\section{Methods}

This study took place within the province of El Estor, Guatemala. Description of recruitment is outlined elsewhere [2]. BMI standards were used to create categories from these children's height and weight measures. We used the WHO BMI cut-off of -1 standard deviation to identify risk factors of malnutrition due to thinness in children [8]. Since height and weight measures were recorded from subjects before and after albendazole dosing (separated by a six month interval), pre and post BMI measurements were calculated. 
The study sample included female and male students, 5 to 17 years old. A total of 1,001 school children were enrolled in this study. The mean age was 9.2 years; other sample characteristics are shown in Table 1. All children had height and weight measures taken, whereas a subsample yielded clinical measures (for anemia and parasite infection classification). Parental consent and children's assent was obtained. IRB approval was granted by the researchers’ University.

Table 1. Independent samples T test with El Estor school children characteristics, Baseline

\begin{tabular}{|c|c|c|c|c|}
\hline & $\mathrm{n}$ & $\%$ & Ave BMI & P-value \\
\hline $\begin{array}{c}\text { Sex } \\
\text { Male } \\
\text { Female }\end{array}$ & $\begin{array}{l}424 \\
467\end{array}$ & $\begin{array}{l}47.6 \\
52.4\end{array}$ & $\begin{array}{l}16.67 \\
16.83\end{array}$ & 0.313 \\
\hline $\begin{array}{c}\text { Age group }^{\mathrm{a}} \\
5-9 \\
10-12 \\
13-17\end{array}$ & $\begin{array}{l}518 \\
262 \\
105\end{array}$ & $\begin{array}{l}58.5 \\
29.6 \\
11.9\end{array}$ & $\begin{array}{l}15.90 \\
17.30 \\
19.64 \\
\end{array}$ & $0.000 * *$ \\
\hline $\begin{array}{l}\text { Residence } \\
\text { Urban } \\
\text { Rural }\end{array}$ & $\begin{array}{l}270 \\
621\end{array}$ & $\begin{array}{l}30.3 \\
69.7\end{array}$ & $\begin{array}{l}16.77 \\
16.75\end{array}$ & 0.907 \\
\hline $\begin{array}{c}\text { Helminth infection }^{\mathrm{b}} \\
\text { No } \\
\text { Yes }\end{array}$ & $\begin{array}{c}72 \\
150\end{array}$ & $\begin{array}{l}32.4 \\
67.6\end{array}$ & $\begin{array}{l}16.96 \\
16.54\end{array}$ & 0.401 \\
\hline $\begin{array}{l}\text { Anemic }^{b} \\
\text { No } \\
\text { Yes }\end{array}$ & $\begin{array}{r}277 \\
14\end{array}$ & $\begin{array}{c}95.2 \\
5.8\end{array}$ & $\begin{array}{l}16.18 \\
16.65\end{array}$ & 0.492 \\
\hline $\begin{array}{l}\text { Albendazole Treatment } \\
3 \text { months } \\
6 \text { months }\end{array}$ & $\begin{array}{l}442 \\
449\end{array}$ & $\begin{array}{l}49.6 \\
50.4\end{array}$ & $\begin{array}{l}16.64 \\
16.86\end{array}$ & 0.151 \\
\hline $\begin{array}{c}\text { Pre-BMI Category }^{\mathrm{a}} \\
\text { Group } 1(<-2 \text { S.D) } \\
\text { Group } 2 \text { ( }-2 \text { to }-1 \text { S.D) } \\
\text { Group } 3 \text { ( }-1 \text { to }+1 \text { S.D) } \\
\text { Group } 4 \text { ( }+1 \text { to }+2 \text { S.D) } \\
\text { Group } 5(>+2 \text { S.D) }\end{array}$ & $\begin{array}{c}13 \\
73 \\
726 \\
82 \\
2 \\
\end{array}$ & $\begin{array}{c}1.5 \\
8.1 \\
81.0 \\
9.2 \\
0.2\end{array}$ & $\begin{array}{l}12.83 \\
14.98 \\
16.61 \\
19.86 \\
26.79\end{array}$ & $0.000 * *$ \\
\hline $\begin{array}{l}\text { Post-BMI Category }^{\mathrm{a}} \\
\text { Group } 1(<-2 \text { S.D) } \\
\text { Group } 2 \text { ( }-2 \text { to }-1 \text { S.D) } \\
\text { Group } 3 \text { ( }-1 \text { to }+1 \text { S.D) } \\
\text { Group } 4 \text { ( }+1 \text { to }+2 \text { S.D) } \\
\text { Group } 5 \text { ( }>+2 \text { S.D) }\end{array}$ & $\begin{array}{c}13 \\
48 \\
546 \\
106 \\
30\end{array}$ & $\begin{array}{c}1.7 \\
6.5 \\
73.5 \\
14.3 \\
4.0\end{array}$ & $\begin{array}{l}12.42 \\
14.76 \\
16.75 \\
19.92 \\
22.64\end{array}$ & $0.000 * *$ \\
\hline
\end{tabular}

\subsection{Analysis}

Comparisons of independent variables were scrutinized (gender, residence, anemia, age, and frequency of helminth medication (2 to 3 doses)). Trends in weight loss or gain were analyzed framed by the dosing period, using $\mathrm{T}$ tests. Pre/post analyses on anemic children were not performed due to low sample size (Table 2). Four binary logistic regression models were constructed using WHO BMI categories as the dependent variable. These categories were combined into a binary variable in which children less than one standard deviation from the mean were tested against all other children. In addition, we analyzed the BMI of children who were greater than one standard deviation above the mean compared to everyone else. We did this pre and post, separated by six months. Analyses were performed using SPSS (version 17.0).

\section{Results}

The majority of children were female (52.7\%), rural residents (64.4\%), and age $5-9$ (57.6\%). At baseline $1.5 \%(n=15)$ students were either extremely thin $(<2$ s.d.) or extremely overweight (> 2 s.d.).

To assess potential selection bias analyses were performed on key characteristics with BMI as the dependent variable (Table 1). As expected, age and BMI group demonstrated a significant difference in BMI averages. No other characteristic shows significance, indicating nonbiased selection. Interestingly, BMI did not differ according to helminth status. When the characteristics were tested six months later, age again displayed its expected differences in BMI, but sex also demonstrated marginal significance $(\mathrm{P}=.074$, Independent Samples $\mathrm{T}$ test) with males posting lower BMI (average 17.1) than females (17.4; data not shown).

Table 2. Paired samples $T$ test with El Estor school children characteristics

\begin{tabular}{|c|c|c|c|c|}
\hline & $\mathrm{n}$ & $\begin{array}{c}\text { BMI (ave.) } \\
\text { Baseline }\end{array}$ & $\begin{array}{c}\text { BMI (ave.) } \\
\text { After } 6 \text { months }\end{array}$ & P-value \\
\hline $\begin{array}{c}\text { Sex } \\
\text { Male } \\
\text { Female }\end{array}$ & $\begin{array}{l}318 \\
362\end{array}$ & $\begin{array}{l}16.64 \\
16.95\end{array}$ & $\begin{array}{l}16.92 \\
17.36\end{array}$ & $\begin{array}{l}0.000 * * \\
0.000 * *\end{array}$ \\
\hline $\begin{array}{c}\text { Age group } \\
5-9 \\
10-12 \\
13-17\end{array}$ & $\begin{array}{c}397 \\
204 \\
75\end{array}$ & $\begin{array}{l}15.92 \\
17.31 \\
20.09\end{array}$ & $\begin{array}{l}16.32 \\
17.66 \\
20.34\end{array}$ & $\begin{array}{c}0.000^{* *} \\
0.001 * * \\
0.072 *\end{array}$ \\
\hline $\begin{array}{l}\text { Residence } \\
\text { Urban } \\
\text { Rural }\end{array}$ & $\begin{array}{l}223 \\
447\end{array}$ & $\begin{array}{l}16.72 \\
16.84\end{array}$ & $\begin{array}{l}17.00 \\
17.24\end{array}$ & $\begin{array}{l}0.010^{* *} \\
0.000 * *\end{array}$ \\
\hline $\begin{array}{c}\text { Helminth infection } \\
\text { No } \\
\text { Yes }\end{array}$ & $\begin{array}{c}37 \\
111\end{array}$ & $\begin{array}{l}17.18 \\
16.43\end{array}$ & $\begin{array}{l}17.44 \\
16.86\end{array}$ & $\begin{array}{c}0.428 \\
0.022 * *\end{array}$ \\
\hline $\begin{array}{l}\text { Anemic } \\
\text { No } \\
\text { Yes }\end{array}$ & $\begin{array}{c}175 \\
--\end{array}$ & $\begin{array}{c}16.71 \\
---\end{array}$ & $\begin{array}{c}16.95 \\
---\end{array}$ & $\begin{array}{c}0.070 * \\
---\end{array}$ \\
\hline $\begin{array}{l}\text { Dosing } \\
3 \text { months } \\
6 \text { months }\end{array}$ & $\begin{array}{l}390 \\
289\end{array}$ & $\begin{array}{l}16.61 \\
17.06\end{array}$ & $\begin{array}{l}17.05 \\
17.32\end{array}$ & $\begin{array}{l}0.000 * * \\
0.000 * *\end{array}$ \\
\hline
\end{tabular}

$* .05<\mathrm{P}<.10 * * \mathrm{P}<.05$

Before and after BMI measures were tested across key characteristics (Table 2). Children grew significantly after six months across all characteristics; strangely, children not infected with parasites did not grow as others. This result across all categories suggests that growth was natural and not linked to a particular health or SES category, let alone to helminth treatment. Marginally significant growth was seen in the oldest age group (age 13-17) suggesting that growth decelerated in this age group as opposed to younger children.

The regression on thinness showed that baseline age stayed in the model as a significant predictor of extreme thinness ( $\mathrm{P}=.011$, Table 3$)$. That is, for every unit increase in age there is a $25 \%$ increase in the likelihood of becoming deleteriously thin (according to WHO categories) controlling for sex, residence, infection status, hemoglobin measures, and albendazole dosing. Only age is associated with unhealthy thinness, before treatment began. 
Table 3. Binary logistic regression on WHO BMI categories

\begin{tabular}{|c|c|c|c|c|c|c|c|c|}
\hline & \multicolumn{4}{|c|}{ BMI thin $^{\mathrm{a}}$ vs BMI non-thin } & \multicolumn{4}{|c|}{ BMI overweight ${ }^{b}$ vs BMI non-overweight } \\
\hline & $\begin{array}{c}\begin{array}{c}\text { Unadjusted OR } \\
\text { (95\% C.I.) }\end{array} \\
\end{array}$ & P-value & $\begin{array}{c}\text { Adjusted OR } \\
(95 \% \text { C.I. })\end{array}$ & P-value & $\begin{array}{c}\text { Unadjusted OR } \\
(95 \% \text { C.I. })\end{array}$ & P-value & $\begin{array}{c}\text { Adjusted OR } \\
(95 \% \text { C.I. })\end{array}$ & P-value \\
\hline $\begin{array}{c}\text { Sex } \\
\text { Baseline }\end{array}$ & $0.564(.21-1.51)$ & 0.255 & $0.615(.24-1.59)$ & & $0.873(.31-2.47)$ & 0.798 & N/A & \\
\hline After 6 months & $0.950(.31-2.92)$ & 0.929 & N/A & & $1.398(.45-4.32)$ & 0.560 & N/A & \\
\hline $\begin{array}{c}\text { Age } \\
\text { Baseline }\end{array}$ & $1.270(1.05-1.53)$ & 0.012 & $1.251(1.05-1.49)$ & $0.011^{* *}$ & $0.826(.65-1.06)$ & 0.126 & $0.831(.66-1.05)$ & 0.120 \\
\hline After 6 months & $0.996(.79-1.26)$ & 0.971 & N/A & & $0.763(.58-1.01)$ & $0.058 * *$ & $0.752(.58-98)$ & $0.036 * *$ \\
\hline $\begin{array}{c}\text { Residence } \\
\text { Baseline }\end{array}$ & $1.112(.43-2.90)$ & 0.828 & N/A & & $0.436(.15-1.28)$ & 0.130 & N/A & \\
\hline After 6 months & $0.494(.16-1.57)$ & 0.231 & $0.510(0.16-1.59)$ & 0.247 & $0.236(.06-.88)$ & $0.032 * *$ & $0.220(.06-.82)$ & $.024 * *$ \\
\hline $\begin{array}{l}\text { Infection } \\
\text { Baseline }\end{array}$ & $0.507(.23-1.63)$ & 0.321 & N/A & & $0.808(.28-2.32)$ & 0.692 & N/A & \\
\hline After 6 months & $1.875(.49-7.19)$ & 0.360 & N/A & & $1.109(.34-3.65)$ & 0.864 & N/A & \\
\hline $\begin{array}{c}\mathrm{Hb} \\
\text { Baseline }\end{array}$ & $0.884(.62-1.27)$ & 0.504 & N/A & & $1.732(1.03-2.91)$ & $0.038 * *$ & $1.642(.99-2.72)$ & $0.053^{*}$ \\
\hline After 6 months & $0.927(.61-1.42)$ & 0.727 & N/A & & $0.988(.61-1.61)$ & 0.961 & N/A & \\
\hline $\begin{array}{c}\text { Dosing } \\
\text { Baseline }\end{array}$ & $0.605(.22-1.68)$ & .334 & N/A & & $1.479(.53-4.15)$ & 0.457 & N/A & \\
\hline After 6 months & $0.380(.10-1.42)$ & 151 & $0.374(.10-1.39)$ & 0.143 & $0.529(.16-1.78)$ & 0.305 & N/A & \\
\hline
\end{tabular}

${ }^{\mathrm{a}}=<1$ standard deviations of BMI

${ }^{b}=>1$ standard deviations of BMI

c after five iterations

*. $05<\mathrm{P}<.10 ; * * \mathrm{P}<.05$

The model focusing on overweight revealed two significant factors, age and residence, both after six months of treatment $(\mathrm{P}=.036$ age, $\mathrm{P}=.024$ residence; Table $3)$. Specifically, for every unit increase in age one expects to see a $25 \%$ decrease in the odds of unhealthy overweight status, according to WHO BMI categories. Secondly, there is an $88 \%$ decrease in the odds of becoming dangerously overweight if one lived in rural settings. Both of these variables controlled for each other as well as sex, infection status, hemoglobin measures, and albendazole dosing. In addition, hemoglobin revealed a marginally significant association. Baseline age stayed in the model during five iterations, but was not significant after controlling for confounders.

\section{Discussion}

This study identifies the effects of a soil transmitted helminth campaign on body bulk in east Guatemalan school children. We found a null effect between helminth influence (infection and/or treatment) and BMI categories. Only baseline age emerges as a predictor for thinness. This association manifests before dosing activities, therefore east Guatemalan children progress toward thinness naturally.

In research from a rural Brazilian setting, $11 \%$ of children were found to be overweight/obese [14]. Their study demonstrates that SES factors lead to overweight/obesity. Likewise, our study demonstrates that residence is a predictor of overweight status; urban settings seem to be riskier nutritional environments in this sample of children; we speculate that marketed processed foods are behind this. We found $8.5 \%$ of the children overweight/obese before dosing and 18.2\% overweight/obese after dosing. However, BMI in a
Guatemalan population has been shown to overestimate fatness in children [15].

The multiple results of the variable age from Table 3 are self-validating because the direction of risk runs opposite whether considering thinness or overweight. That is, we find that as a Guatemalan child ages he/she is more likely to become naturally thin, but the direction reverses with overweight status only after intervention (a younger child is more likely to become overweight after treatment). Other studies show children's growth in positive association with age $[16,17,18]$, or, among immigrant children or children in developing countries, demonstrate level or no growth with aging [19]. Yet another study, also done in Guatemala [20] shows retarded growth in early childhood only. Our study is unique in demonstrating diminishing growth (BMI) in relation to age. However, these latter researchers allow for patterns of unaccounted sexual maturity or immigration that may affect growth patterns in adolescents [20]. Our finding of greater gain in females suggest sexual or hormonal changes underlying growth variety.

\subsection{Strengths and Limitations}

We had moderate to low sample size in clinical measures (helminth/hemoglobin), but substantial size with BMI measured children. Distribution of BMI categories (Table 1) follow the proportions of normally distributed data. We relied on two binomial logistical regression models, whereas one polytomous regression model could statistically suffice; we split the analysis into two phases to maintain analytic power. Logistic regression has advantages over multivariate regression analysis, namely, being more robust. Lastly, we controlled for various other demographics, and albendazole dosing category, in the final analysis, and checked for selection bias. 


\section{Summary}

Treatment for intestinal helminths shows no impact on BMI growth in Guatemalan children. BMI indicators detect both under and over malnutrition using the same set of standards [8]. Furthermore, the significant growth in younger children (ages 5-9) and the marginally significant decline in growth in older children (ages 13-17) suggest that BMI as a tool for measuring body bulk growth in children may work for some situations and environments, but not all situations [15]. We suggest the continued discussion of weight for height, and height for age, constructs as supplements to BMI interpretations. We do not favor BMI as the sole nutrition screening tool for children in developing countries.

\section{References}

[1] Braghetta A. Drawing the connection between malnutrition and lack of safe drinking water in Guatemala. J Am Water Works Assoc2006; 98: 97-106.

[2] Sorensen W,Cappello M, Bell D,DiFedele L, Brown M. Polyhelminth infection in east Guatemalan children. J Glob Infect Dis 2011; 3: 25-31.

[3] Bonello D. 'Green hunger' as starvation stalks fertile Guatemala. Available at:http://news.yahoo.com/green-hunger-starvationstalks-fertile-guatemala-142625718.html. (accessed on August 9, 2011).

[4] Central Intelligence Agency. The World Factbook; Field listing, population below poverty line. Available at: http://www.travlang.com/factbook/fields/2046.html. (accessed on May 18, 2009).

[5] Levey A, Coresh J, Balk E, Kausz A, Levin A, Steffes M, Eknoyan G. National Kidney Foundation practice guidelines for chronic kidney disease: evaluation, classification, and stratification. Ann Intern Med 2003; 139: 137-47.

[6] Pelletier DL, Frongillo EA. The effects of malnutrition on child mortality in developing countries. Bull World Health Org 1995; 73: 443-8.

[7] Grantham-McGregor S, Yin Bun C, Cueto S, Glewwe P, Richter L, Strupp B. Child development in developing countries:
Developmental potential in the first 5 years for children in developing countries. Lancet 2005; 369: 60-70.

[8] World Health Organization. News: New WHO child growth standards catch on. Bull World Health Organ 2011; 89: 250-251.

[9] Shrimptom R, Rokx C. (2012). The double burden of malnutrition; a review of global evidence. Washington DC: World Bank, 2012.

[10] Gragnolat M, Marini A. Latin America and the Caribbean Region, Health and poverty, Guatemala. Available at: http://wwwwds.worldbank.org/external/default/WDSContentServer/WDSP/I B/2006/05/26/000090341_20060526105522/Rendered/PDF/36206 0GU0GUAPA120Health1Paper501PUBLIC1.pdf. (accessed on June 15, 2012).

[11] Cole T, Flegal K, Nicholls D, Jackson A. Body mass index cut offs to define thinness in children and adolescents: International survey. Br Med J 2007; 335: 1-8.

[12] Martorell R. Is wasting (thinness) a hidden problem in Latin America's children? J Nutr 2001; 131: 1133-4.

[13] Frontini M G, Bao W, Elkasabany A, Srinivasan SR, Berenson G. Comparison of weight-for-height indices as a measure of adiposity and cardiovascular risk from childhood to young adulthood: The Bogalusa heart study. J ClinEpidemiol 2011; 54: 817-22.

[14] Pinto Guedes D, Divino Rocha G, Rocha Martins Silva AJ, Mourão Carvalhal J, Coelho EM. Effects of social and environmental determinants on overweight and obesity among Brazilian schoolchildren from a developing region. Rev Panam Salud Publica 2011; 30: 295-302.

[15] Schroeder DG, Martorell R. Fatness and body mass index from birth to young adulthood in a rural Guatemalan population. N Engl J Med 1999; 70 (supp): 137S-44S.

[16] Barker DJP, Osmond C, Forsen TJ, Kajantie E, Eriksson JG. Trajectories of growth among children who have coronary events as adults. N Engl J Med 2005; 353:1802-9.

[17] Eriksson JG, Forsen T, Tuomilehto J, Winter PD, Osmond C, Barker DJP. Catch-up growth in childhood and death from coronary heart disease: Longitudinal study. Br Med J 1999; 318: 427-31.

[18] Ong KKL, Ahmed ML, Emmett PM, Preece MA, Dunger DB. Association between postnatal catch-up growth and obesity in childhood: Prospective cohort study. Br Med J2000; 320: 1244.

[19] Deheeger M, Akrout M, Bellisle F, Rossignol C, Rolland-Cachera M. Individual patterns of food intake development in children: A 10 months to 8 years of age follow-up study of nutrition and growth. PhysiolBehav 1996; 59: 403-7.

[20] Martorell R, Schroeder DG, Rivera JA, KaplowitzHJ. Patterns of linear growth in rural Guatemalan adolescents and children. J Nutr 1995; 125 (4 Suppl): 1060S-7S. 